\title{
The (in)visibility of Arab women in political journalism
}

Noha Mellor

While the expansion of the Arab news and media industries over the past two decades has provided unprecedented opportunities for women to access and succeed in the media field, journalists are still not expected to question the political order. The rise of satellite television and transnational Arab media since the mid-1990s has allowed Arab women journalists to capitalize on the new opportunities for work, not only as producers and anchors, but also as field reporters. Arab women journalists have also pursued career opportunities outside their native countries in the Middle East/North Africa (MENA) region: Many satellite channels are based in Dubai; and other Western-subsidized Arabic services (including BBC Arabic, Russia Today, France 24 and Deutsche Welle) are in the U.K., France, Germany, Russia and the U.S.A.

Because of the high demand for new journalists, some Arab news outlets have even hired people with only a few years of experience. Many women have taken advantage of such openings as a means of establishing themselves in journalism, particularly in jobs as presenters, while a few of them have managed to get jobs as field reporters. Many women, however, have not managed to fend off the newsroom's discrimination against them. Indeed, I argue, that only larger societal changes in each Arab country will bring an end to discrimination. Arab women are often expected to serve as positive role models and representatives of their country, reflecting a modern image of the nation, instead of challenging the government and championing the social reforms so acutely needed. Additionally, Arab women journalists are generally expected to support rather than challenge the patriarchal order in times of political turbulence, in order to preserve the perceived social stability provided by adhering to the status quo. Those few who defy the status quo may risk putting their future career prospects in jeopardy or be forced to abandon the high status political beat which is largely dominated by men journalists.

This chapter discusses some of these challenges faced by Arab women journalists. Recent turmoil and repercussions against political reforms in many Arab countries have exacerbated the challenges. I argue that emerging political challenges have silenced many women media professionals from expressing political views opposing to the ruling regimes. The political turmoil in the region has, moreover, only intensified the challenge of women journalists and activists to get their voices heard and sustain their presence in public spheres, which remain largely dominated by men. Although women media professionals, of which some are also political activists and bloggers, joined their male counterparts in street protests across the region during the 'Arab Spring', societal and political restrictions forced women to withdraw from the public spaces once the old regimes were overthrown. This, I argue, is reminiscent of past events such as the Algerian women's struggle alongside Algerian men against the French occupation until independence in 1962 when women were forced to abandon political activities and expected to wear the veil and return to domestic duties (Kutschera, 1996). Women's unrewarded sacrifices in recent years demonstrate that Arab political and media spheres have been structured by a deep-rooted patriarchal order. In this chapter, I begin with a discussion of some of the current challenges facing Arab women journalists. In the second half, I provide several examples of such 
challenges in Egypt, demonstrating a collision of political culture and journalism which combines to preserve the patriarchal status quo of journalistic practice in Egypt.

\section{Gender in the newsroom}

With the proliferation of satellite television targeting Arabic-speaking audiences across the world, political news has gained more prominence (Mellor, 2011, 90). Soft news, which focuses on, for instance, everyday issues such as gender equality or problems in the education and health care systems in Arab countries, has not been prioritized by news institutions. Given a wide-spread assumption that that political news requires broad knowledge about history, foreign affairs, and diplomacy, opportunities for job promotions are usually restricted to those working on the political beat rather than culture and art. Journalists who work with political news are thus regarded as more knowledgeable and have a higher professional status than their colleagues reporting on social or cultural affairs. Women journalists who work in political news often tend to present themselves as tough and fearless, particularly when they are in front of the camera, in order to legitimize their position as a political reporter. This attitude in television reporting is adopted in order to add to their image as professional journalists, distinct from other women in entertainment genres who are not directly exposed to violent images of war and conflict or political struggle (Mellor, 2012). For some of those women who work as field reporters in conflict-stricken parts in the region, being women can give them access to certain places or to talking to sources who might be uncomfortable talking to male journalists (Palmer \& Melki, 2018).

In Qatar, where the international network al-Jazeera is based, national Qatari newsrooms including alJazeera network tend to hire women journalists from Arab and Asian countries. However, the Qatari government does not allow these women to cover local corruption cases or pursue investigative journalism and in-depth reporting in some political cases (Kirat, 2016). Generally, in the Gulf region, women managed to enter the journalistic field only a few decades ago, and Gulf news institutions' policies tend to provide more training and promotion opportunities for men rather than women journalists which reflects the under-appreciation of women's work in the journalism field (Kirat, 2004). Saudi Arabia has some, although relatively few, prominent Saudi women journalists, but many of these women work outside of Saudi Arabia, often due to the harsh criticism they faced inside the kingdom for working in newsrooms where the majority of journalists are male. The highly outspoken Nadine alBudair, for example, criticized Muslim clerics in 2016 after three Muslim Belgians committed suicide bombings in Brussels ; al-Budair called such clerics "hypocrites" for continually saying that the terrorists behind such attacks did not represent Islam, without directly condemning the terror act and explaining in detail how those terrorists deviated from the teachings of Islam (Memri, 2016). In fact, al-Budair gained notoriety back in 2009 when she triggered a hot debate with her satirical article, "Me and My Four Husbands." In this article, published in the Egyptian privately-owned newspaper, Al-Masri alYoum, she asked if she, as a Muslim woman, could have four husbands in the same way that a Muslim man is allowed to have up to four wives (Memri, 2010).

Indeed, before changing the culture within newsrooms, wider structural changes are needed in Arab societies. A range of factors such as gender discrimination, sexual harassment and lack of enabling legal and social environment discourages Arab women from entering journalism. Those who manage to enter it may find themselves confined to specific, lower status, roles (Melki \& Mallat, 2016). The recent 
turmoil in the region has undoubtedly pushed political news back to the top of the news outlets' agenda, and the so-called 'Arab Spring' has contributed to shaking up power structures, not only regarding governance and political structures, but also within newsrooms where women journalists demanded equal opportunities in the political beat as field reporters and witnesses to verbal and physical abuse against women in public places.

\section{Women facing two battles}

Women's participation in the early uprisings across the Arab region since 2011 represented a new face of Arab women as activists and agents of change, in contrast to the stereotypical media image of Arab women as passive and submissive (Al-Malki et al. 2012). Women took to the street in Egypt, Tunisia, Libya, Bahrain, Syria and Yemen, to protest against the status quo and demand political reforms. One example is the Bahraini activist and blogger Zainab al-Khawaja, who later went on hunger strike following the arrests of her father, husband and brother-in-law (Guardian, 2016). When the late former President of Yemen, Abdallah Saleh, criticized allowing men and women to congregate in public spaces and organisations, including media institutions, claiming that this gender-mixing was un-Islamic, Yemini women joined men in the street to protest against Saleh's rule (Care International, 2013). In Egypt, some of the many young women who felt empowered by the 2011 uprising have released their testimonies of the protests (see, for instance, el-Tounsi, 2011).

Following the uprisings, women's gains in terms of equal civil rights remained uncertain. According to the World Economic Forum's Global Gender Gap report (2012), women's political participation in the Middle East declined slightly in 2012 compared to 2011, and their involvement in Arab parliaments remains at a low 14 percent (Care International, 2013, 7). Violence against women has escalated to an alarming level, and sexual harassment, in particular, has become the main reason for keeping women away from street protests (Care International 2013, 7-8).

Many women journalists aided in the uprisings and provided relevant news coverage. Libyan women journalists, for example, helped set up opposition newspapers during the unrest in 2011, but later their employment situation worsened in the wake of the civil war and the armed conflict among rival factions. Women journalists in Tunisia continue to experience harassment in the workplace, and their responsibilities have been largely confined to covering local news, and so they have not managed to become editors (Deutsche Welle, 2015). Egyptian women journalists have also been prevented from covering events in the field, with their editors citing the dangerous field as an excuse to send male reporters instead "There were times when I was deterred from covering field events and was told that male reporters would be required because they were more capable of facing risks", said one woman during a Deutsche Welle symposium in 2015 discussing the problems facing women journalists in the Middle East (cited in Deutsche Welle, 2015).

Women correspondents in conflict-stricken areas such as the Palestinian territories and Iraq have often found a new mission in their reportage. The 2003 war in Iraq, for instance, helped to open up the journalism sector for women in the tens of television and radio stations launched after the fall of Saddam and which offered new work opportunities for those eager to enter the journalism field. That said, conflict in Iraq subsequently worsened the security situation and intensified sectarianism; this has had a heavy impact on the working conditions of Iraqi women journalists. Several have since faced threats of violence and assaults by both political and religious factions (al-Rawi, 2010). A recent survey showed that nearly seventy-nine percent of sampled women journalists in Iraq said that they were 
subject to sexual harassment while at work (al-Arabiya, 2013). In fact, the Iraqi Women's Journalists Forum (IWJF) held a conference in Baghdad in 2015, in part, to discuss sexual harassment, and then commissioned a study of the implications of this on women journalists. The conference attendees concluded that the prevalent social rules of separating girls and boys from an early age has had negative impacts on both women and men, resulting in a sexist culture and gender segregation in the newsroom. The deteriorating security situation in Iraq has, moreover, exacerbated sexual harassment against women (ICSSI Baghdad, 2015). The IWJF suggested a number of measures to protect women, such as changing school curricula to raise awareness of the problem and introducing legislation that would harden the legal penalty for crimes involving violence against women.

\section{Using sexual violence to expel women from public spaces}

In Egypt, sexual harassment has reportedly reached an epidemic level, with almost all Egyptian women between the age of 10 and 35 having been subjected to various forms of sexual harassment at some point (el Deeb, 2013). Politically-motivated sexual assault of women activists, bloggers and journalists began well before the 2011 uprising. In 2005, in a notorious incident known as Black Wednesday, statehired thugs and security forces sexually assaulted many of the more than 500 women taking part in the mass demonstrations organised by Kefaya [Enough] movement against President Mubarak's regime. Both government supporters and critics say part of the reason the response to this incident was so large is that the security services have long used women as pawns to fight individuals. In Arab societies, a family's honor is often directly linked to a woman's perceived virtue. The 2005 incident prompted a massive protest spearheaded by a number of women activists and journalists in a campaign called "the street is ours" in collaboration with the Egyptian Center for Women's Rights and the new Women's Research Center (Sika, 2014).

In 2011 the organisation Reporters Without Borders warned female journalists not to travel to Cairo to cover the unrest following instances of grievous sexual assaults on several foreign women journalists. For example, French journalist Caroline Sinz was brutally assaulted by a mob in Tahrir Square. CBS News chief foreign affairs correspondent, Lara Logan, was sexually assaulted by a crowd that altogether had between 200 and 300 men (Sherwood, 2011). People posting reactions to Logan's rape via social media supported taking action against such violence targeting women reporters. News blogs were particularly articulate in challenging patriarchal authority and interpretations of rape such as those which blamed rape victims for not being sufficiently cautious (Harp, Loke \& Bachmann, 2014). The incident was not the first assault against an American journalist: Mona Eltahawy, an Egyptian-American journalist who formerly worked for Reuters, also experienced sexual assault. Eltahawy was detained for twelve hours in November 2011 by Cairo security forces and was physically assaulted while in detention. Eltahawy was previously lauded by American media for her coverage of the uprising and for writing about the Egyptian blogger, Aliaa Elmahdy, who posted naked images of herself in October 2011. Elmahdy intended her blog posts as a dramatic protest against the marginalisation of women, sexual harassment and violence against women, and increasing restrictions on women's freedom of speech (Abid, 2017, 159).

In March 2011, soon after Mubarak bowed to the mounting protests against him and stepped down, women protestors including bloggers and activists began to suffer from increasing sexual assaults, particularly in Cairo. This violence represents the result of the repeated collision between protestors, 
including women, and security forces. The assaults made women feel, as the perpetrators intended, pushed back to the sidelines. Exacerbating the indignity was the subjection of many women protestors to so-called virginity tests (Abid, 2017, 159). Egyptian women protested virginity tests permitted by the Supreme Council of the Armed Forces (SCAF) on women activists who were arrested as they protested in Tahrir Square. Those women were detained in military prisons where they were sexually assaulted under the guise of virginity tests. For instance, a young Egyptian activist, Samira Ibrahim, was amongst those women protestors in Tahrir Square who were violently dispersed by the military police and were tortured and forced into receiving a virginity test. Ibrahim was the only woman who brought a case, front of Egyptian courts prompting a mixed reaction of Egyptians, many of whom blamed Samira for initiating the case and some even blamed women protestors of congregating in Tahrir Square in the first place. A military court exonerated the military doctor who carried out the virginity tests on the female protestors which was seen as a major setback for Ibrahim. Later, in December 2011, women protestors outside the Egyptian Cabinet offices were targeted by the armed forces and many women were subjected to sexual violence triggering a massive women mass demonstration on 17 December under the slogan "the women of Egypt are a red line" (FIDH, 2014, 14). Following another protest in June 2014, an Islamic cleric, Sheikh Sami Abdel Qawi, attributed harassment to women's dress code implying that "westernised" clothing style was to blame for such attacks on women and promoting the victim-blaming discourse (Langohr, 2014).

In Jordan, too, the state-controlled discourses circulated by and through Jordanian news media's coverage of issues related to female virginity. This had the effect of legitimising patriarchal control of women's bodies in the name of protecting women's virginity. In this respect, both the state and family patriarchs enforce their control to inspect and protect women's virginity. Virginity itself is reduced to an intact hymen which can be inspected and confirmed via virginity tests, and in so doing, the state is complicit in upholding discriminatory practices against women (Mahadeen, 2015). This humiliation triggered strong public protest, especially on social media.

Indeed, the concept of female honour can lead to different forms of violence against women (Baker, Gregware \& Cassidy, 1999). In this respect, maintaining virginity remains one means of controlling women's sexuality in a culture where non-virgin single women are often regarded as source of family dishonour if their husbands cannot verify their virginity on the wedding nights. As many crimes of violence against women go uninvestigated, the state essentially sends the message giving perpetrators of sexual violence a kind of immunity from prosecution and calling the public sphere unsafe for women. This urges women to minimize their presence in public spaces and implies that "men are responsible for protecting their women from other men" (Ahmad-Zaki, and Abd AlHamid, 2014). As the Egyptian journalist Habiba Mohsen (2012) put it, asking why a woman went out in public is the first reaction when trying to bring up cases of sexual assault [to court]. 'Blaming it all on the woman for being present at a demonstration, blaming the "weaker link of the chain", seems to be a satisfying solution for some sectors of Egyptian society.' 
With the rising number of women participating in public protests since the 2011 revolution in Egypt, the rate of sexual violence against women has increased rapidly. Such violence against women can be read

"as an attempt to expel them from public spaces and to re-inscribe pre-revolutionary limits" (AhmadZaki, and Abd AlHamid, 2014), and targeted violence against women could contribute to maintaining the gendered status quo pushing women away from participating in political activities whether as street demonstrator or as a political reporter. Sexual violence against women remains unchallenged given how honour and shame are related to women's sexuality. Assaults on women usually end up intimidating the male relatives, including fathers and brothers, of women protestors, who are urged to stay silent in the name of protecting their honour. For women journalists, staying in public spaces and being exposed to such a risk of assault is a form of activism as Rawya Rageh, an Egyptian broadcast journalist put it, "In societies where women have to fight to have control over their own bodies, have to fight to reassert their right in the public space-being a woman journalist is almost a form of activism" (Yakupitiyage, 2016).

Thus, although women joined men in the public squares in Egypt demanding political freedoms and the end of autocracy, "unlike men, women face two battles: the first for political change and the second to obtain a real change of their societal status to become fully equal to their male counterparts" (Heideman \& Youssef, 2012, p. 14). The following section provides several examples from the Egyptian broadcasting industry demonstrating the constant struggle of women journalists who faced a twofold battle inside the field: one for professional recognition inside the newsrooms largely dominated by male editors and the second to sustain their presence in the political beat.

\section{Driving women away from the political beat: the case of Egyptian news media}

Women journalists' response to street protests in 2011 took different shapes and they assumed various roles. Some women wanted to emulate the Western role of the journalist as a watchdog. Another group of journalists has emerged that has sought to assume a new role for journalists as activists. Examples include women journalists like Mona Shazly, Reem Maged, Liliane Daoud and Dina Abdel Rahman. Bouthaina Kamel, a veteran journalist and activist, defied the regime then in power by standing in the 2012-presidential elections as an alternative to those representing the military or Islamist institutions, but she did not receive enough signatures to make the ballot. Nevertheless, many women journalists were forced to either abandon the political beat or leave Egypt altogether.

Hala Sarhan's case represents the challenges facing women journalists when, against the odds, they find themselves covering the political beat for their news organisation. Sarhan's career began with hosting light talk shows and ended with serious political programmes after the toppling of Mubarak. Throughout her successful career, Sarhan was marked by her daring style and choice of topics - such as prostitution in Egypt. Not surprisingly, the state and its media accused her of attempting to tarnish Egypt's reputation by discussing such sensitive issues. Sarhan remained outside Egypt between 2008 and 2011 after she claimed that Mubarak's government conspired against her to stop her show, "They came after me because they couldn't put pressure on me. They couldn't use me and I wouldn't be part of their gang. I didn't serve their regime," she said (quoted in Hope, 2011). Sarhan returned to Egyptian television in 2011 with a political show called Nassbook (People's Book), a name that was meant to 
parody Facebook, and that depended on live interaction with viewers via social media sites such as Facebook and Twitter. The show was taken off air, however, following Sarhan's discussion of the potential complicity of the military in the physical assault and killing of 2011 protesters. She left journalism altogether following the 2013 coup when the Egyptian army chief, Abdel Fattah el-Sisi, led a coalition to remove the former President Mohamed Morsi in 2013. Shortly after, el-Sisi suspended the Egyptian constitution. His government curtailed dissent amongst journalists, activists and NGOs.

Other Egyptian women have risen to journalistic fame since Mubarak's fall. Reem Maged is an example of an outspoken activist woman willing to criticise Mubarak's regime, and later, the Supreme Council of the Armed Forces (SCAF) and President Morsi's government. This critical stance caused her political show to be taken off air for two years (2011-2013); when she returned with a show about women's issues, it did not last long. Maged was interrogated by security forces when she interviewed a socialist activist who talked about torture inside military prisons. She was also called up for an investigation during Morsi's rule, because she apparently insulted the judiciary system (Ahram Online, 2015). Her program Gamea Moanas Salem ("Feminine Plural") was broadcast on the privately-owned satellite channel ONTV, with the aim of discussing sensitive social issues pertaining to women, but it was suspended after only two episodes - no explanation was given. Commenting on the possible reasons behind that decision, Maged declared, "I do not understand the logic of banning, I see it as arrogance and guardianship. What makes it painful to me is that I willingly haven't been working for two years [...] During these two years, I insisted on not working for a non-Egyptian channel [...] for emotional rather than professional reasons" (quoted in Ahram Online, 2015). Maged was interviewed on a handful of occasions and told one interviewer that senior ONTV officials had informed her about the emerging political pressures to suspend her show. To this she replied, "We should not accept any authority that acts like a guardian on the Egyptian people, telling them what they should watch, and what they should not watch," (quoted in Dawoud, 2015).

Dina Abdel Rahman also faced unfair dismissal. She was suspended from the private channel Dream TV and later from another private channel Capital Broadcasting Center $(C B C)$, owned by the Egyptian businessman, Mohammad al-Amin, for expressing pro-revolutionary views. Abdel Rahman was sacked from Dream TV following her televised interview with a retired air force major, when she challenged him to provide evidence of his accusation that two presidential candidates would implement an American agenda. The retired military leader also criticized Abdel Rahman for airing one journalist's criticism of Supreme Council of the Armed Forces regarding the attack on young activists, and thus turning the people against the army. He suggested that Abdel Rahman should only select respectable journalists as guests. She sarcastically replied by asking him to provide her a list of such respectable figures. The show was suddenly disrupted following that conversation, and Abdel Rahman's sacking was publicly announced (el-Gundy, 2011a). Another woman journalist who criticized the Supreme Council of the Armed Forces was the British-Lebanese Liliane Daoud, who joined the Egyptian ONTV channel in 2011, and hosted a political show, The Full Picture, but left the channel and was forced out of Egypt in 2016. Daoud was accused of criticizing the military in her show; consequently, when ONTV was sold to another businessman who was supportive of the military, Daoud's contract was not renewed (Ensor, 2016).

TV presenter Mona al-Shazly also had to abandon political talk shows, choosing instead to host a light family show on the $C B C$ satellite channel (Adly, 2014). al-Shazly was famous for her interview with Wael Ghonim, the secret administrator of "We are all Khaled Said" Facebook group, which mobilized protesters for the 25 January uprising. The interview was broadcast live on 7 February 2011, one day 
before Mubarak stepped down. She also displayed photographs of protestors killed during the early days of the revolution (al-Hady, 2011). al-Shazly also challenged Hisham Qandil, the prime minister during the period that the Brotherhood movement was in power in 2012-2013, when the activists were calling for the government's dismissal regarding their dissatisfaction with the economic and security policies (Ahram Online, 2013a).

Finally, one of the most controversial figures in Egypt since 2011 has been Bothaina Kamel, the first woman to run in Egypt's presidential elections in 2012, having already been well-known for her political activism during Mubarak's rule. Kamel's broadcasting career began in 1992 with a radio program called Itirafat Layliyya ("Nightly Confessions"); it soon became very popular. However, it was banned in 1998, after the criticism from the Religion Programs Committee. The reason given was that the show aired listeners' phone calls in which they shared intimate personal stories, touching on taboo issues such as sexual abuse and premarital sex. Kamel was accused of tarnishing Egypt's reputation abroad by hosting a religiously inappropriate show, which prompted Kamel to announce that Islamic fundamentalism had also penetrated state institutions. Kamel then moved to the Saudi-owned satellite channel Orbit to broadcast a program called Argouk Ifhamny ("Please Understand Me") between 2000 and 2011, similar to her previous radio programme. During that period, she also became involved in a few political activist campaigns, including the Kefaya [Enough] movement against Mubarak's plan to pass on Egypt's rule to his son. Kamel also co-founded Egyptian Women for Change in 2010 to promote political and social transformation; as would be expected, she joined the protests against Mubarak in 2011. Following the ousting of Mubarak, Kamel returned to state television but she soon accused her editors of marginalizing her, following her open criticism of the military and the Muslim Brotherhood. Kamel was recommended for the "International Women of Courage Award", but declined it, because it was sponsored by the U.S. Department of State. Accepting the award, , she said, meant accepting the state that supplied the Egyptian military with weapons used against Egyptian revolutionaries (Antoun, 2012). Kamel was suspended and questioned during Morsi's rule for being critical on air of the Brotherhood; in fact, she described some state media as being mouthpieces for the Brotherhood while reading news bulletins on state television (Shahine, 2012). She said that everyone should tell the truth, even at the cost of one's life, indicating that those opposing the Brotherhood tended to risk theirs (Shahine, 2012). Kamel alleged she was accosted in 2013 by a group of men whom she described as Muslim Brotherhood supporters; they smashed her car and physically attacked her. (Ahram Online, 2013b).

These women demonstrate the collision of political culture and journalism in a society where the current conception of masculinity preserves the patriarchal status quo (whether by the military or Islamic movements), while assigning a secondary role to women. The political sphere then appears as a field naturally dominated by (strong) male leaders, while women who seek to challenge top leadership positions (such as Bothaina Kamel) or hold those leaders to account, may just end up being marginalized to soft news and social issues, if not dismissed from the journalistic field altogether. The political environment mediates female journalists' opportunities on the political beat, in particular, and women's opportunities in the political sphere, in general. Strong male leaders embody the image of patriotic manhood (usually confined to military men), while women are assigned the role as nurturing supporters and motherhood, serving as symbols of a patriarchal nationalist ideology. Men and women, therefore, have separate, designated gendered places within their respective fields. 
Thus, the battle for women Arab journalists is not just about fairer representation in editors' positions or as reporters and anchors; the real battle is against masculine nationalist politics. Numerous women have actively participated in challenging a long dormant public sphere debates and views. Their challenge now is resisting the constraining political environment that has pushed many women away from taking their rightful place in political journalism.

\section{Conclusion}

Since the independence of many Arab states in the 1950s and 1960s, calls have been issued for the remodeling of Arab identity, distinct from Western values and ideologies. Arab women have played a central role in the cultural production of the nation in the Arab states, which saw a symbol of their own progress in allowing and extending educational programmes for girls, even in conservative Islamic societies such as that in Saudi Arabia; nevertheless, later the states were irked by the educated women's demands for equal citizenship rights as those enjoyed by men. Such demands particularly irked Islamic institutions such as the Committee for the Promotion of Virtue and the Prevention of Vice in Saudi Arabia who later accepted women's participation in public life, as long as such participation reconciles with the teachings of Islam, which includes enforcing sex segregation in public places. States and institutions then aimed at distinguishing the struggle of Arab women from Western feminist values by preserving the existing gender relations and the patriarchal order within Arab societies (al-Ali 2000, p. 55). On the other hand, reconciling Islamic and religious values with universal rights was not an easy task for Islamist groups; for instance, during their short rule in Egypt, the Muslim Brotherhood issued a statement in March 2013 denouncing the proceedings of the UN Commission on the Status of Women aiming to end violence against women. The Brotherhood denounced the declaration as a step that would "lead to complete disintegration of [Muslim] society and would certainly be the final step in the intellectual and cultural invasion of Muslim countries" (cited in Fecteau, 2017, 81).

Although massive protests that erupted in many Arab countries since 2011 have brought global attention to the demands of Arab populations for their political rights, protests have not typically brought real change to the marginalized position of women in the region. Arab women actively participated in street protests, although they were expected to withdraw from the political sphere once old regimes had been overthrown. Women's participation, as the Egyptian feminist Nawal El Saadawi once wrote, "was not needed except in military or economic crises, in war or when their men or the state needed them to work outside their home. Women are brought up to sacrifice their lives for others, to be rewarded later in Paradise after their death" (El Saadawi, 2006, 47). This illustrates that politics in the MENA region remains a largely masculine and conservative affair aimed at maintaining the patriarchal order under the guise of embracing tradition and nation-building.

On a positive note, if women journalists and activists struggle to get heard in traditional media, their voices have become louder and clearer than ever before on social media (see e.g. Radsch \& Khamis, 2013; al-Rawi, 2014). These voices will continue to challenge present conception of women's and minorities' rights in the future. Social media activism, particularly that initiated and maintained by women in the Middle East, has had an impact on legitimating and reinforcing women's rights to speak and be heard in public and in attracting world attention, albeit sometimes temporarily, to women's dilemmas in that part of the world. 


\section{References}

Abid, Fatimaezzahra (2017) Arab Feminists' Sexual Revolution and Social Activism After the 2011 Arab Spring: Aicha Ech-Channa's À Hautes Voix as a case study. In Jochen Lobah \& Hamza Tayebi (eds.) Trajectories of Change in Post-2011: Challenges and Prospects. Rabat: Hanns Seidel Foundation Morocco, pp 158-173.

Adly, Ahmad (2014) Mona al-Shazly leaves political shows. Elaph, 14 February 2014, http://elaph.com/Web/Entertainment/2014/2/877221.html\#sthash.likxfH2T.dpuf

Ahmad-Zaki, Hind and Abd AlHamid, Dalia. 2014. "Women as Fair Game in the Public Sphere: A Critical Introduction for Understanding Sexual Violence and Methods of Resistance." Jadaliyya, July 9, 2014. http://www.jadaliyya.com/Details/30930/Women-As-Fair-Game-in-the-Public-Sphere-A-CriticalIntroduction-for-Understanding-Sexual-Violence-and-Methods-of-Resistance

Ahram Online (2013a) Egypt government won't resign, says PM Qandil, Arham Online, 14 Feb 2013, http://english.ahram.org.eg/NewsContent/1/64/64792/Egypt/Politics-/Egypt-government-wont-resign,says-PM-Qandil.aspx

Ahram Online (2013b) Ex-presidential hopeful Bothaina Kamel attacked by 'Morsi supporters'. Ahram Online, 6 Oct 2013, http://english.ahram.org.eg/NewsContent/1/64/83353/Egypt/Politics-

/Expresidential-hopeful-Bothaina-Kamel-attacked-by-.aspx

Ahram Online (2015) Egyptian Presenter Reem Maged's New TV Show Suspended, 15 May 2015, http://english.ahram.org.eg/NewsContent/1/64/130340/Egypt/Politics-/Egyptian-presenter-ReemMageds-new-TV-show-suspend.aspx

Al-Ali, Nadje, 2000. Secularism, gender and the state in the Middle East. The Egyptian women's movement. Cambridge: Cambridge University Press.

Al-Hady, Omar (2011) The Martyrs of the 25th of January Revolution'. Al-Masry Al-Youm, 12 Feb. 2011, http://today.almasryalyoum.com/article2.aspx?ArticlelD=287608\&IssuelD=2044

Al-Malki, Amal, David Kaufer, Suguru Ishizaki \& Kira Dreher (2012) Arab Women in Arab News: Old Stereotypes and New Media. London: Bloomsbury Academic.

Al-Rawi, Ahmad K. (2010), 'Iraqi women journalists' challenges and predicaments', Journal of Arab \& Muslim Media Research 3: 3, pp. 223-236.

Al-Rawi, Ahmed (2014) Framing the online women's movements in the Arab world, Information, Communication \& Society, 17:9, 1147-1161

Antoun, Naira (2012) Profile: Bothaina Kamel, Ahram Online, 5 Apr 2012, http://english.ahram.org.eg/NewsContent/36/122/38566/Presidential-elections-/Presidential-electionsnews/Profile-Bothaina-Kamel.aspx

Ayish, M., 2011. Understanding Arab women's role in media industries. An empowerment-based perspective. Journal of Arab \& Muslim Media Research, 3 (3), 191-206. 
Baker, N., Gregware, P, \& Cassidy, M. A. (1999). Family killing fields: Honor rationales in the murder of women. Violence Against Women, 5 (2), 164-184.

Care International (2013) Arab Spring or Arab Autumn? Women's political participation in the uprisings and beyond: Implications for international donor policy, POLICY REPORT, London: Care International.

Dashti, Ali A. \& Hesham Mesbah (2016) The perceptions of female media professionals in Kuwait about their job: an empowerment perspective, Feminist Media Studies, 16:2, 276-292

Dawoud, Khaled (2015) Reem Maged versus the Government. Atlantic Council, 22 May 2015, http://www.atlanticcouncil.org/component/content/article?id=24393:reem-maged-versus-thegovernment

Deutsche Welle (2015) After the Arab Spring: harassment and discrimination are the main challenges for women journalists. Deutsche Welle Arabic, 15 June 2015.

El Deeb, Bouthaina. 2013. "Study on Ways and Methods to Eliminate Sexual Harassment in Egypt." UN Women. http://harassmap.org/en/wp-content/uploads/2014/02/287 Summaryreport eng low-1.pdf

El Gundy, Zeinab (2011a) Famous Egyptian TV host sacked after challenging ex-army officer on air. Ahram Online, 25 July 2011, http://english.ahram.org.eg/NewsPrint/17266.aspx

El Gundy, Zeinab (2011b), Egypt's SCAF members interviewed in special joint broadcast Wednesday. Ahram Online, 19 October 2011, http://english.ahram.org.eg/NewsContent/1/64/24575/Egypt/PoliticsEgypts-SCAF-members-interviewed-in-special-joint-b.aspx

El Saadawi, Nawal (2006) Creativity, Dissidence and Women, Quaderns de la Mediterrània, http://www.iemed.org/publicacions/quaderns/7/045 ElSaadawi.pdf

El Tounsi, Amani (2011) Amani: A girl from Tahrir. Cairo: Shabab Books (in Arabic).

Ensor, Josie (2016) Egypt Expels Former BBC Journalist Liliane Daoud. Daily Telegraph, 28 June 2016, http://www.telegraph.co.uk/news/2016/06/28/egypt-expels-former-bbc-journalist-liliane-daoud/

Fecteau, André (2017) The Arab Spring and Women's Rights Activism on Facebook. In Larbi Touaf, Soumia Boutkhil \& Chourouq Nasri (eds.) North African Women after the Arab Spring: In the Eye of the Storm. Basingstoke: Palgrave, pp 77-96.

FIDH, Nazra for Feminist Studies, New Women Foundation, and The Uprising of Women in the Arab World (2014). Egypt: Keeping Women Out. Sexual Violence Against Women in the Public Sphere. https://www.fidh.org/lMG/pdf/egypt women final english.pdf

Guardian (2016) Bahrain detains activist Zainab al-Khawaja and her one-year-old son, The Guardian, 14 March 2016, https://www.theguardian.com/world/2016/mar/14/bahrain-detains-activist-zainab-alkhawaja-and-one-year-old-son

Harp, Dustin, Jaime Loke \& Ingrid Bachmann (2014) Spaces for Feminist (Re)Articulations: The blogosphere and the sexual attack on journalist Lara Logan, Feminist Media Studies, 14:1, 5-21

Heideman, Kendra \& Youssef, Mona (eds) (2012) Reflections on Women in the Arab Spring. Women's Voices from Around the World, Woodrow Wilson International Center for Scholars, Washington, DC. 
Hope, Bradley (2011) Egypt's 'Oprah' returns to television. The National, August 24, 2011, http://www.thenational.ae/news/world/middle-east/egypts-oprah-returns-to-television

ICSSI Baghdad(2015) The Iraqi Women Journalists Forum Breaks the Silence about Sexual Harassment of Girls and Women in Iraq, Oct 5, 2015, http://www.iraqicivilsociety.org/archives/4720

KIRAT, MOHAMED (2004) A profile of women journalists in the United Arab Emirates, The Journal of International Communication, 10:1, 54-78

Kirat, Mohamed (2016) A profile of journalists in Qatar: traits, attitudes and values, The Journal of International Communication, 22:2, 171-187

KUTSCHERA, CHRIS 1996 'Algeria 's fighting women', The Middle East, April, pp. 40-41

Langohr, Vickie (2014) “New President, Old Pattern of Sexual Violence in Egypt." Middle East Research and Information Project, July 7, 2014. http://www.merip.org/mero/mero070714

Mahadeen, Ebtihal (2015) Media, State, and Patriarchy, Feminist Media Studies, Vol. 15(5): 763-778

Masini, E.B., 1994. The creative role of women in a changing world: the case of women in developing countries. Leonardo, 27 (1), 51-56.

Melki, Jad P. \& Sarah E. Mallat (2016) Block Her Entry, Keep Her Down and Push Her Out, Journalism Studies, 17:1, 57-79

Mellor, Noha (2011) Arab journalists in transnational media. NY: Hampton Press.

Mellor, Noha (2012) Hearts of Steel. Feminist Media Studies. Vol. 12(2): 180-194.

MEMRI (2010) Saudi Journalist: Why Is Polygamy Only for Men? Special dispatch, no. 2773, January 27, 2010, https://www.memri.org/reports/saudi-journalist-why-polygamy-only-men

MEMRI (2016), Saudi TV Host Nadine Al-Budair Takes to Task Apologists Who Claim Terrorists Have Nothing to Do with Islam and the Muslims: They Emerged from Our Schools and Universities, clip. No. 5436, April 2, 2016, https://www.memri.org/tv/saudi-tv-host-nadine-al-budair-takes-task-apologistswho-claim-terrorists-have-nothing-do-islam/transcript

Mohsen, Habiba (2012) What made her go there? Samir Ibrahim and Egypt's virginity test trial. AlJazeera, 16 March 2012, https://www.aljazeera.com/indepth/opinion/2012/03/2012316133129201850.html

Palmer, Lindsay \& Jad Melki (2018): Shape Shifting in the Conflict Zone, Journalism Studies, 19(1): 126142

Radsch, Courtney C. \& Sahar Khamis (2013) In Their Own Voice: Technologically mediated empowerment and transformation among young Arab women, Feminist Media Studies, 13:5, 881-890

Shahine, Gihan (2012) The media power game. Ahram Weekly, Issue 1127, 20 - 26 December 2012, http://weekly.ahram.org.eg/News/598.aspx 
Sherwood, Harriet (2011). Egypt protests: plea to keep women reporters out of Cairo withdrawn. The Guardian, 25 November 2011. https://www.theguardian.com/world/2011/nov/25/egypt-protestsreporters-women-safety

Sika, Nadia. 2014. "An Egyptian Spring for Arab Women?" In Arab Spring and Arab Women: Challenges \& Opportunities, (ed.) Mohamad Olimat. New York: Routledge.

The Guardian (2011) Women have emerged as key players in the Arab spring, 22 April 2011, https://www.theguardian.com/world/2011/apr/22/women-arab-spring

Van den Wljngaard, R., 1992. Women as journalists: incompatibility of roles? Africa Media Review, 6 (2), 47-56.

Yakupitiyage, Tharanga (2016) Violence Against Women Journalists Threatens Media Freedom, IPS News, 28 April 2016, http://www.ipsnews.net/2016/04/violence-against-women-journalists-threatensmedia-freedom/ 